SŁAWOMIR BANASZAK

Uniwersytet im. Adama Mickiewicza

w Poznaniu

\title{
FOKUS: TECHNIKA I JEJ ZASTOSOWANIE W BADANIACH EDUKACYJNYCH
}

AвSTRACT. Banaszak Sławomir, Fokus: technika i jej zastosowanie w badaniach edukacyjnych [Focus Group Interview: the Technique and its Application in Social Research]. Studia Edukacyjne nr 45, 2017, Poznań 2017, pp. 19-28. Adam Mickiewicz University Press. ISSN 1233-6688. DOI: 10.14746/ se.2017.45.2

A Focus group interview (FGI), the focused group, focus groups or just focus are the definitions of data collection techniques which, after several decades of development, have become an important part of research plans in social sciences. Placing the focus on communication techniques leads us to combine analyses consisting of interview and observation. It also raises the question whether the focus, which by definition combines and directly expresses the strengths and weaknesses of communication techniques and the strengths and weaknesses of observation techniques, allows achieving some kind of methodological synergy. In addition, the essence of measurement in science and - more closely - in social sciences seems to be an important context for the empirical functioning of the focus and for researchers preferring this technique of data collection.

Key words: methodology of social sciences, research methods in social sciences, focus group interview, data collection techniques

\section{Wprowadzenie}

Fokus, badanie fokusowe bądź w skrócie FGI (ang. focus group interview) to współczesne określenia znanej techniki gromadzenia danych w naukach społecznych. Można zapytać, dlaczego właśnie ta technika skłania do szczególnej refleksji odnośnie jej empirycznego statusu? Dlatego, że „ma już swoje lata" i dlatego, że nowe czasy, nowoczesne społeczeństwa oraz nowoczesne badania empiryczne stawiają coraz to nowe wyzwania przed wywiadami w ogóle, a przed wywiadami grupowymi w szczególności.

Celem niniejszego tekstu jest przybliżenie techniki zogniskowanego wywiadu grupowego, a przede wszystkim osadzenie jej w strukturze pozosta- 
łych technik gromadzenia danych. Uboczny niejako skutek tych zadań stanowi odniesienie się do dyskusji między zwolennikami badań jakościowych oraz badań ilościowych. Jednakże, uboczny nie oznacza nieistotny. Przeciwnie - właśnie ta dyskusja oraz wyraźna tendencja do zawłaszczania fokusów jako wyłącznej domeny badań jakościowych stały się impulsem do podjęcia przedmiotowego zagadnienia. Niniejsze ujęcie nie ma więc nic wspólnego z podręcznikowym podejściem do prezentacji zastosowań techniki, lecz jest dokonywane $\mathrm{w}$ kontekście wcześniejszych doświadczeń w stosowaniu fokusów w badaniach społecznych i z zamiarem wypracowania względnie oryginalnego stanowiska w tej dziedzinie, $\mathrm{z}$ jednoczesnym wskazaniem na możliwości zastosowań w badaniach edukacyjnych.

\section{Metody, techniki i pomiar w badaniach społecznych}

Aby porozumiewać się $\mathrm{w}$ jakimś języku teoretycznym czy metodologicznym, co absolutnie oczywiste, potrzebna jest zgoda. Przynajmniej co do głównych kategorii. Tak właśnie jest z metodami i technikami. A wydaje się, że nie tylko nie ma zgody co do treści tych pojęć, lecz także - być może wskutek tego stanu rzeczy - wprowadza się dodatkowe kategorie, jak strategie czy badania. Po drodze zapomniano już, że mamy jeszcze do dyspozycji, zgodnie $\mathrm{z}$ rodzimą tradycją badawczą, procedury. Wreszcie, nawet $\mathrm{w}$ obrębie podstawowych metod i technik występuje brak zgodności co do kwalifikowania poszczególnych „aktów” empirycznych jako jednego bądź drugiego rodzaju.

Najlepszy przykład stanowi obserwacja, która klasycznie zaliczana jest do technik gromadzenia danych (techniki obserwacyjne versus techniki komunikacyjne). Niemniej, niektórzy autorzy podręczników skłonni są do uznania obserwacji za metodę, nie podając przy tym żadnych konkretnych argumentów. Czy odpowiada za to chęć generowania innowacyjnych nazw i podziałów, czy językowa kalka z angielskiego - tego w tym miejscu nie rozstrzygniemy.

Warto jednak przytoczyć, co na temat obserwacji pisze Mieczysław Łobocki w popularnym skądinąd podręczniku:

Obserwacja, jako jedna z metod badań pedagogicznych, stanowi osobliwy sposób postrzegania, gromadzenia i interpretowania poznawanych danych $\mathrm{w}$ naturalnym ich przebiegu i pozostających w bezpośrednim lub pośrednim zasięgu widzenia i słyszenia obserwatora ${ }^{1}$.

Dalej następuje przegląd definicji obserwacji, który wieńczy następujący fragment:

\footnotetext{
${ }^{1}$ M. Łobocki, Wprowadzenie do metodologii badań pedagogicznych, Kraków 2009, s. 226.
} 
Rozumiana a ten sposób obserwacja ma do spełnienia szczególną rolę w badaniach pedagogicznych. Przede wszystkim umożliwia poznawanie zachowania dzieci, młodzieży i dorosłych $\mathrm{w}$ jego naturalnych warunkach. Często ułatwia sformułowanie hipotezy roboczej, pozwala sprawdzić poprawność twierdzeń czy uogólnień wyprowadzonych na podstawie innych metod lub technik badawczych i stanowi ważne ich uzupełnienie czy dopełnienie ${ }^{2}$.

Wreszcie, w dalszej części rozdziału autor, oprócz rodzajów obserwacji wypowiada się o technikach obserwacji. Dowodzi tedy, że jest ona metodą, ale w poszczególnych odmianach również techniką ${ }^{3}$.

Nie da się takiego stanowiska pogodzić ani z rozumieniem obserwacji w antropologii kulturowej ${ }^{4}$, ani z polską tradycją badań w naukach społecznych, ani z dokonanym ongiś przez wybitnego badacza Kazimierza Doktóra ${ }^{5}$ podziałem technik obserwacyjnych, ani ze współwystępowaniem obserwacji z technikami wywiadów, w tym zogniskowanego wywiadu grupowego. Warto natomiast skorzystać z dokonanego ongiś rozróżnienia i, dokonując koniecznej adaptacji, określić obserwację jako jawną, neutralną ze względu na postawę badacza oraz pomocniczą ze względu na „rolę obserwacji w całości programu badawczego" ${ }^{\prime}$.

Sprawdźmy więc, jak się ma rzecz z podstawowymi kategoriami empirycznymi w naukach społecznych, czyli z metodą i techniką. Otóż, okazuje się, że występuje tu względnie duża różnorodność pojęć i odpowiadających im czynności podejmowanych w toku postępowania badawczego. Szczególną uwagę warto zwrócić na pojęcie metody. Ale wpierw na ogólne pojęcie pomiaru w nauce oraz pomiaru w naukach społecznych.

Jak ujmują to autorzy znakomitej książki na temat technik pomiaru:

(...) pomiar naukowy jest to zabieg poznawczo-praktyczny, którego celem jest ustalenie stanów natężenia czynników czy przynależności stanów badanych obiektów do poszczególnych klas jakościowych i - o ile to możliwe - liczbowe ujęcie wyników pomiaru. Mówiąc potocznie, celem pomiaru jest dostarczenie danych pozwalających na jakościowy albo ilościowy opis zjawisk czy procesów 7 .

Po pierwsze, zwróćmy uwagę na charakter pomiaru - zarówno poznawczy, jak i praktyczny. Autorzy mają na myśli wprawdzie to, że każdy pomiar wiąże się z jakimś rodzajem ingerencji w społeczną (edukacyjną, kulturową,

${ }^{2}$ Tamże.

3 Tamże, s. 228.

${ }^{4}$ J. Monaghan, P. Just, Social and Cultural Anthropology. A Very Short Introduction, New York 2000.

${ }^{5}$ Por. K. Doktór, Przedsiębiorstwo przemysłowe. Studium socjologiczne Zakładów Przemystu Metalowego „H. Cegielski", Warszawa 1964.

${ }^{6}$ Tamże, s. 51.

7 R. Suchocka, B. Suchocki, J. Walkowiak, Techniki pomiaru w socjologii, Poznań 1985, s. 101. 
ekonomiczną, organizacyjną) rzeczywistość, niemniej podkreślmy, że w przypadku badań edukacyjnych ów praktyczny charakter może także oznaczać zmianę. Po wtóre, polscy badacze silnie akcentują fakt, dziś wciąż zapoznany, że rzeczywistość można opisywać jakościowo bądź ilościowo. Rzeczywistość per se nie ma z góry ustalonego charakteru. Chyba też nie ma potrzeby deklaracji, czy zamierzamy ją ujmować w ten czy inny sposób. Tym bardziej zaś wyznaczania wyraźnej i nieprzekraczalnej linii demarkacyjnej dzielącej jedno i drugie podejście.

Okazuje się także, iż od pomiaru w nauce jako całości do pomiaru w ramach poszczególnych dyscyplin, w szczególności w interesujących nas naukach społecznych, droga nie jest tak daleka, jak mogłoby się wydawać. Wprawdzie przedmiot w naukach społecznych "cechuje się stanami, które są częściowo niedostępne bezpośredniej obserwacji” ${ }^{8} \mathrm{i}$ przez to mierzenie tak zwanych świadomościowych czynników ma charakter intuicyjny i nie poddający się jednoznacznie konfirmacji lub dyskonfirmacji.

Ponadto, pomiar w naukach społecznych oznacza zwykle, nie inaczej jest w przypadku fokusów, pozyskiwanie informacji o obiektach od nich samych. Mam na myśli drogę komunikacyjną. I nie ma tu różnic w porównaniu na przykład z działalnością lekarza, ale tylko w pierwszej fazie - wywiadu właśnie. Etap następny w diagnostyce medycznej oznacza jednak potwierdzenie ustaleń oraz przy puszczeń z wywiadu za pomocą badań laboratoryjnych. Badaczom społecznym z kolei pozostaje obserwacja jako swego rodzaju „technika kontrolna".

\section{Postulowane ujęcie metod i technik w badaniach empirycznych}

Szum informacyjny wokół pojęć metody i techniki, jaki jest od dawna widoczny, nie służy wypracowaniu jednolitego, konkretnego i zrozumiałego języka metodyki badań społecznych. Niemniej, warto zaproponować takie rozumienie obu pojęć, które wydaje się spełniać minimalne kryteria komunikatywności oraz - jednocześnie - stanowi odniesienie do stosowanych w naukach społecznych planów badawczych? ${ }^{9}$.

Będziemy więc nazywać metodą taki sposób rozwiązania problemu naukowego, który zawiera założenia ontologiczne i epistemologiczne dotyczące przedmiotu objętego poznaniem. Sposób ten ma swoją strukturę wyrażoną

\footnotetext{
8 Tamże, s. 110.

${ }^{9}$ Por. w zakresie relacji wzajemnych między empirią, teorią a praktyką S. Banaszak, Teoria i empiria - kilka uwag metodologicznych i praktycznych, [w:] Pedagogika jako humanistyczno-społeczna nauka stosowana: konsekwencje metodologiczne, D. Kubinowski, M. Chutoriański, Kraków 2017.
} 
między innymi w sekwencji kroków badawczych oraz zasad postępowania. Technika badawcza to konkretny zespół czynności podejmowanych w wyróżnionej fazie postępowania badawczego. Oznacza to, że można mówić na przykład o technikach problematyzacji, konkretyzacji, operacjonalizacji, technikach doboru próby, wreszcie o technikach otrzymywania danych (tu właśnie będą się lokować fokusy) czy technikach analizy.

Niniejsza propozycja jest względnie niezależna od tego, czy badacz ma zamiar analizować rezultaty badawcze jakościowo czy ilościowo ${ }^{10}$. Rzeczywistość bowiem jest znacznie bogatsza i nie daje się zaszufladkować jako jednego lub drugiego rodzaju. Poza tym, dla pojęcia metody najistotniejsze jest związanie jej z założeniami co do ontologii i epistemologii życia społecznego. Jest więc znaczące, czy badacz opowiada się za scjentyzmem, czy za antynaturalizmem, czy za indywidualizmem, czy antyindywidualizmem, za historyzmem czy ahistoryzmem, za podejściem teleologicznym czy bezkierunkowym. Człony tych antynomii konstytuują metodę.

Z kolei, techniki badawcze to szerokie pojęcie, które, w zależności od etapu postępowania, odnosi się do bardzo konkretnych czynności i zadań. Stosowane zaś obiegowo pojęcie technik badawczych jest raczej równoznaczne z pojęciem technik otrzymywania danych (lub inaczej technik gromadzenia danych czy technik gromadzenia informacji). I tu będzie się zaznaczał wspomniany już podział na techniki komunikacyjne i obserwacyjne.

\section{FGI pośród technik wywiadu}

Techniki wywiadu, obok ankiet, stanowią podstawowe techniki komunikacyjne (w tradycyjnym podziale techniki otrzymywania danych na: komunikacyjne i obserwacyjne). Obok swobodnej rozmowy, wywiadu pogłębionego oraz wywiadu kwestionariuszowego ${ }^{11}$ tworzą jedną empiryczną rodzinę. Jednakże, w jej obrębie pozostają jedyną techniką, której cechą swoistą jest grupowa interakcja oraz dyskusja. Rodzi to, rzecz jasna, pewne konsekwencje metodologiczne, na przykład związane z przygotowaniem scenariusza, kompetencjami oraz doświadczeniem moderatora (lub moderatorów, jeśli jest ich więcej), a także organizacją przestrzeni, w której odbywa się badanie ${ }^{12}$.

${ }^{10}$ Por. S. Banaszak, Edukacja menedżerska w społeczeństwie wspótczesnym. Studium teoretyczno-empiryczne, Poznań 2011.

${ }_{11} \mathrm{~J}$. Lutyński, Analiza otrzymywania informacji w badaniach z zastosowaniem wywiadu kwestionariuszowego, [w:] Analizy i próby technik badawczych w socjologii, t. 4 - Wywiad kwestionariuszowy w świetle badań metodologicznych, red. Z. Gostkowski, J. Lutyński, Wrocław 1972.

${ }_{12}$ Por. R.A. Krueger, M.A. Casey, Focus Groups. A Practical Guide for Applied Research, Thousand Oaks, CA, 2000; por. też D.L. Morgan, Focus Groups, Annual Review of Sociology, 1996, 22. 
Dane pochodzące $\mathrm{z}$ wywiadów, czy to $\mathrm{w}$ bezpośredniej analizie zapisu czy ujęte już $\mathrm{w}$ formę transkrypcji, mogą być różnie analizowane ${ }^{13}$. I rzecz nie tylko w tym, że można zastosować rozmaite techniki analizy danych, lecz w tym, że podejścia do analizowanych danych mogą być różne. Jak stwierdza David Silverman ${ }^{14}$, pozytywiści upatrują w nich bezpośredniego dostępu do faktów wierząc, że uzyskuje się informacje rzetelne i trafne. Z kolei, emocjonalna optyka widzenia świata zakłada, że jest możliwe dotarcie do autentycznych doświadczeń badanych, z udziałem obserwacji jako techniki towarzyszącej. Wreszcie, konstrukcjonizm to pogląd, który wikła badacza w proces konstruowania znaczeń, co w istocie oznacza współudział badacza i badanego w wytwarzaniu "tekstu". Oczywiście, nie są to absolutnie nowe poglądy, a raczej twórcze odniesienie się do z dawna inicjowanej dyskusji na temat antynomii aktywizm-pasywizm, czyli wokół pytania, kto lub co wyznacza rezultaty poznania.

Z pewnością, wszystko to można odnieść do fokusów, kiedy zdecydujemy się je ulokować w obrębie wywiadów. Ponadto, wspomniana wcześniej obserwacja, w związku z dynamiką sytuacji grupowej, a także, niekiedy, treści poruszanej problematyki badawczej stanowi istotny rys FGI. Generalnie rzecz biorąc, wywiady nie istnieją bez obserwacji, a fokusy - tym bardziej. Po co bowiem żmudna, czasochłonna i pracochłonna organizacja badania fokusowego, kiedy nie ma się zamiaru analizować zachowań respondentów? W takim wypadku „lepsza” może okazać się ankieta. Zatem, owo zrośnięcie się wywiadów w ogóle, a fokusów w szczególności, jest elementem formującym ich formę i zarazem treść.

Autorzy znakomitego podręcznika badań w naukach społecznych Chava Frankfort-Nachmias i David Nachmias poświęcają niewiele uwagi fokusom. Odwołując się do klasycznego już tekstu Roberta K. Mertona i Patricii L. Kendal ${ }^{15}$, lokują FGI w obrębie wywiadów osobistych, które są prowadzone według planu. Wskazują na cztery charakterystyczne cechy fokusów ${ }^{16}$. Pierwszą jest udział respondentów, którzy reprezentują określony typ doświadczeń pożądanych z punktu widzenia problematyki badawczej. Drugą stanowi odwołanie się do sytuacji zaistniałych przed wywiadem i wcześniej analizowanych. Trzecią cechą jest plan wywiadu wskazujący na istotne tematy wyznaczone między innymi przez hipotezy badawcze. To ważna uwaga autorów, gdyż obecnie dostrzegalna jest tendencja do niestawiania hipotez

${ }^{13}$ J. Cieślińska, Styl przywództwa dyrektora szkoty a rozwiązywanie konfliktów. Zwiad badawczy, Studia Edukacyjne, 2014, 33, s. 253-258.

${ }^{14}$ D. Silverman, Interpretacja danych jakościowych. Metody analizy rozmowy, tekstu i interakcji, przekł. M. Głowacka-Rajper, J. Ostrowska, Warszawa 2009, s. 114-115.

${ }_{15}$ R.K. Merton, P.L. Kendal, The Focused Interview, American Journal of Sociology, 1946, 51.

${ }^{16}$ C. Frankfort-Nachmias, D. Nachmias, Metody badawcze w naukach społecznych, przekł. E. Hornowska, Poznań 2001, s. 251. 
w badaniach z wykorzystaniem technik wywiadu, fokusów w szczególności. Wreszcie, czwartą cechę stanowi skupienie się wokół doświadczeń respondentów mających bezpośredni związek z badaną problematyką.

Amerykańscy badacze akcentują także rolę osoby przeprowadzającej wywiad jako potrafiącej selekcjonować informacje istotne i potrafiącej kontrolować je poprzez stałe odnoszenie do problematyki badawczej. Dodajmy, że niemniej istotne znaczenie ma scenariusz badania fokusowego, bowiem jego konstrukcja stanowi ogólną orientację badawczą. Moderator, prócz scenariusza, winien legitymować się pewnym doświadczeniem $\mathrm{w}$ relacjach z grupą, a także doświadczeniem $\mathrm{w}$ realizacji badań empirycznych.

Wypada jednak podkreślić, że jeśli mamy do czynienia z językiem, który oferuje przypuszczalnie więcej, to warto go zastosować w metodologicznym, empirycznym żargonie. Dzięki temu uściślimy znaczenie niektórych kategorii i unikniemy być może naukowej „wieży Babel”. Ponadto, warto w tym miejscu przywołać słowa Vilfredo Pareto, który mawiał, że nie ma przeszkód by zastępować jedne kategorie innymi, lecz tylko w tym wypadku, gdy są to lepsze kategorie, czyli takie, które jaśniej i bardziej jednoznacznie odnoszą się do analizowanych zjawisk i procesów. W przeciwnym razie takie zbiegi nie mają sensu.

Pora więc zdefiniować, czym jest focus group interview. Jolanta Lisek-Michalska przytacza następującą definicję FGI: „technika badawcza, w której poprzez współdziałanie, interakcję grupy uczestników, badacz zbiera niezbędne dla jego celów informacje” ${ }^{17}$. Stwierdza także, że „zogniskowany wywiad grupowy nie jest techniką jednorodną; w praktyce badawczej występują różne jego odmiany, wyodrębnione ze względu na bardzo rozmaite kryteria"18. Są to między innymi czas trwania, liczba uczestników, częstotliwość badania, kryteria doboru uczestników, sposób traktowania narzędzia badawczego, cel, sposób organizacji sesji, czy rodzaj kontaktu badacza z badanymi ${ }^{19}$.

Warto odnieść się do kilku z nich. Czas trwania tak zwanej sesji fokusowych może się oczywiście bardzo różnić, niemniej stosowany podział na brief group oraz extended group wyraża zwykle również rozległość problematyki ${ }^{20}$. W pierwszym przypadku jest to zwykle jeden temat, w drugim natomiast stawia się kilka problemów oraz wykorzystuje kilka dodatkowych technik.

Z kolei kryterium liczby uczestników pozwala wyróżnić tak zwaną mini group oraz focus group. Pierwsza z nich to badanie na około 4-6 osobach, druga dotyczy 10-12 osób. Ale w tym przypadku również nie tylko chodzi o liczbę respondentów, lecz o problematykę oraz głębię jej rozpoznania. Zwykle

\footnotetext{
${ }^{17}$ J. Lisek-Michalska, Badania fokusowe. Problemy metodologiczne i etyczne, Łódź 2015, s. 16.

18 Tamże, s. 17.

19 Tamże, s. 17-21.

${ }^{20}$ Tamże.
} 
przyjmuje się, że minifokusy znajdują zastosowanie przy poruszaniu społecznie wrażliwych spraw i że dzięki kameralnej atmosferze badacz jest w stanie dotrzeć do głębszych pokładów opinii, postaw, wartości itp.

Pozostałe kryteria także wskazują na elementy empirycznego badania, które w naukach społecznych niejako pośredniczą w pomiarze oraz, co nie powinno nikogo dziwić, w analizie i interpretacji wyników. Warto jednak sformułować tezę, że jakkolwiek wyróżnianie kolejnych typów badania fokusowego ukazuje nam jego bogactwo i poszerza wachlarz zastosowań, to nie zmienia „zasady działania”. A jest nią, jak się wydaje, grupowa dyskusja, spór, znajdowanie argumentów przez uczestników, a z perspektywy badacza - uprawdopodobnienie głoszonych opinii. Również za sprawą ich konfrontacji z zachowaniami, gestami, mimiką itp.

\section{Zakończenie}

Fokus to technika gromadzenia danych, która nie tylko wydaje się trafna z punktu widzenia podstawowych cech badań społecznych, lecz także daje bardzo dobre rezultaty badawcze w połączeniu ze swego rodzaju kontrolą w postaci obserwacji zachowań uczestników. Rzecz jednak w tym, by analiza zachowań dokonywana była na podstawie rzeczywistej i możliwie sprawdzonej wiedzy, a nie, jak mawiał Platon, na gruncie cieni, widziadeł rzeczywistych idei.

Nauki społeczne, w szczególności socjologia i pedagogika, wykorzystują fokusy od dość dawna, choć losy omawianej techniki były dość zawiłe, jako że początkowo z trudem przekonywano się do formuły dyskusji grupowej $\mathrm{w}$ nielicznym gronie i opartej na przygotowanym scenariuszu. Należy przyznać, że pragmatyczni przedstawiciele nauk o zarządzaniu, a zwłaszcza praktycy zarządzania, na przykład marketerzy, najwcześniej i najpełniej docenili walory FGI ${ }^{21}$. Dlaczego? Ponieważ fokusy dawały wgląd w potrzeby respondentów, prezentowane postawy, a nawet uznawane wartości, co przekładało się bezpośrednio na niezbędną wiedzę dla tych, którzy projektują produkty lub usługi.

Pedagogiczne zastosowania wywiadów grupowych wydają się równie szerokie i - z punktu widzenia możliwości kontroli określonych czynników - owocne. Przy czym, warto podkreślić, iż technika ta może łączyć zarówno zwolenników tak zwanych podejść jakościowych, jak i ilościowych. Może też być stosowana na równych etapach postępowania badawczego: jako autonomiczna technika pomiaru, technika uzupełniająca, technika organizująca 1987.

${ }^{21}$ J.F. Templeton, Focus Groups. A Guide for Marketing and Advertising Professionals, Chicago 
zwiad badawczy, technika właściwego pomiaru. W tym znaczeniu, jej zastosowanie nie odbiega znacząco od, na przykład, zastosowań wywiadów pogłębionych, wraz z ich jakościową analizą ${ }^{22}$.

Pośród szerokiego wachlarza zastosowań w naukach o edukacji, szczególnie ważne wydają się badania:

1) ukierunkowane na opinie badanych o sprawach aktualnych i wrażliwych jednocześnie, np. przeobrażeniach systemu oświaty, konkretnych rozwiązaniach praktycznych stosowanych w placówkach oświatowych itp.;

2) skupione wokół idei generowania rozwiązań praktycznych określonych kwestii, np. efektywności rozwiązywania konfliktów w Radzie Pedagogicznej, prowadzenia spotkań z rodzicami, kierunków rozwoju placówki itp.;

3) osób nieletnich, w tym dzieci, które mogą opierać się na scenariuszach uwzględniających zadania do wykonania, wykorzystujące testy projekcyjne oraz inne techniki aktywizujące uczestników.

Wszystkie wymienione sfery empirycznego pomiaru wymagają, rzecz jasna, bardzo dobrego przygotowania scenariusza, niezwykle uważnego oraz reaktywnego moderowania dyskusji, a także uwzględnienia wielokontekstowej natury zebranych informacji w toku analiz i interpretacji wyników. To jednak nic absolutnie nowego w metodyce empirycznych badań w naukach społecznych.

\section{BIBLIOGRAFIA}

Babbie E., Podstawy badań społecznych, przekł. W. Betkiewicz i in., Wydawnictwo Naukowe PWN, Warszawa 2009.

Banaszak S., Edukacja menedżerska w społeczeństwie współczesnym. Studium teoretyczno-empiryczne, Wydawnictwo Naukowe UAM, Poznań 2011.

Banaszak S., Teoria i empiria - kilka uwag metodologicznych i praktycznych, [w:] Pedagogika jako humanistyczno-społeczna nauka stosowana: konsekwencje metodologiczne, red. D. Kubinowski, M. Chutoriański, Oficyna Wydawnicza Impuls, Kraków 2017.

Cieślińska J., Styl przywództwa dyrektora szkoły a rozwiązywanie konfliktów. Zwiad badawczy, Studia Edukacyjne, 2014, 33.

Doktór K., Przedsiębiorstwo przemystowe. Studium socjologiczne Zakładów Przemystu Metalowego „H. Cegielski”, Książka i Wiedza, Warszawa 1964.

Frankfort-Nachmias C., Nachmias D., Metody badawcze w naukach społecznych, przekł. E. Hornowska, Zysk i S-ka Wydawnictwo, Poznań 2001.

Kmita J., Wykłady z logiki i metodologii nauk, PWN, Warszawa 1975.

Krueger R.A., Casey M.A., Focus Groups. A Practical Guide for Applied Research, Sage, Thousand Oaks, CA 2000.

Lisek-Michalska J., Badania fokusowe. Problemy metodologiczne i etyczne, Wydawnictwo Uniwersytetu Łódzkiego, Łódź 2013.

${ }^{22}$ Por. $\mathrm{w}$ tym przedmiocie rozważania metodologiczne oraz analizy empiryczne: J. Śmietańska, Talent menedżerski w oświacie, Poznań 2016. 
Lutyński J., Analiza otrzymywania informacji w badaniach z zastosowaniem wywiadu kwestionariuszowego, [w:] Analizy i próby technik badawczych w socjologii, t. 4 - Wywiad kwestionariuszowy w świetle badań metodologicznych, red. Z. Gostkowski, J. Lutyński, Zakład Narodowy im. Ossolińskich, Wrocław 1972.

Łobocki M., Wprowadzenie do metodologii badań pedagogicznych, Oficyna Wydawnicza Impuls, Kraków 2009.

Merton R.K., The Focussed Interview and Focus Groups. Continuities and Discontinuities, Public Opinion Quarterly, 1987, 51.

Merton R.K., Kendal P.L., The Focused Interview, American Journal of Sociology, 1946, 51.

Monaghan J., Just P., Social and Cultural Anthropology. A Very Short Introduction, Oxford University Press, New York 2000.

Morgan D.L., Focus Groups, Annual Review of Sociology, 1996, 22.

Nowak S., Metodologia badań socjologicznych, PWN, Warszawa 1970.

Silverman D., Interpretacja danych jakościowych. Metody analizy rozmowy, tekstu i interakcji, przekł. M. Głowacka-Rajper, J. Ostrowska, Wydawnictwo Naukowe PWN, Warszawa 2009.

Suchocka R., Suchocki B., Walkowiak J., Techniki pomiaru w socjologii, Wydawnictwo Naukowe UAM, Poznań 1985.

Śmietańska J., Talent menedżerski w oświacie, Wydawnictwo Naukowe UAM, Poznań 2016.

Templeton J.F., Focus Groups. A Guide for Marketing and Advertising Professionals, Probus, Chicago 1987. 